
cited.

\title{
MENGKAJI LEGALITAS PERATURAN MAHKAMAH AGUNG NOMOR 2 TAHUN 2012 TENTANG PENYESUAIAN BATASAN TINDAK PIDANA RINGAN DAN JUMLAH DENDA DALAM KUHP
}

\author{
Mohamad Rifki \\ (Mahasiswa Pascasarjana Magister Ilmu Hukum Universitas Gadjah Mada, meraih Sarjana Hukum (S.H.) dari \\ Universitas Diponegoro (2009), dan bekerja sebagai Perancang Peraturan Perundang-undangan pada Biro \\ Hukum dan Organisasi, Sekretariat Jenderal, Kementerian Kelautan dan Perikanan)
}

(Email: m.rifki.bho@gmail.com)

Received: 16 Februari 2018; Accepted: 24 Agustus 2018; Published: 19 September 2018

\begin{abstract}
:
Besides court function, the Supreme Court also has rule function, counseling function, supervisor function, and administrative function. Judges as an organ on Supreme Court must be differentiated with Supreme Court as a State Institution. Judges can be a law maker on their verdict (Judge made-law), because Judges are not only a mouthpiece of the law (la bouche de la loi), instead they also considered to know the law (Ius Curia Novit). However, the Regulation of Supreme Court as an implementation of its rule function can't be stated as a law making (rechtsvinding), because the Regulation of Supreme Court is not a part of Law Making, but rather Rule Making. Regulation of Supreme Court Number 2 Year 2012 about Adjustment on the Limitation of Minor Crime and Fine on KUHP is one of the regulation that has been made by the Supreme Court as a State Institution. This article will analyze the legality of the Regulation of Supreme Court based on the authority given by the act or constitution, and also analyze it from the regulation concerning the drafting of act.
\end{abstract}

Keyword: Supreme Court, Law Maker, Rule Function, Legality of Supreme Court Regulation maupun antar masyarakat, mengingat sistem

\section{Pendahuluan}

\section{A. Latar Belakang}

Indonesia telah menegaskan dalam konstitusinya sebagai negara hukum (rechtstaat). ${ }^{1}$ Sehingga, keberadaan suatu peraturan perundang-undangan menjadi penting sebagai landasan melaksanakan suatu kewenangan atau hubungan baik antara pemerintah dengan masyarakatnya

1 Lihat Pasal 1 ayat (3) Undang Undang Dasar Negara Republik Indonesia Tahun 1945 (selanjutnya disebut UUD NRI Tahun 1945). hukum yang dianut Indonesia adalah civil law yang lebih mengutamakan statutory law atau undang-undang tertulis ${ }^{2}$ meskipun tetap mengakui adanya kearifan lokal dan hukum adat sebagai salah satu komponen hukum.

Berdasarkan hal tersebut, maka tidak mengherankan apabila dalam konstitusi diberikan atribusi terhadap beberapa hal untuk diatur atau ditetapkan dalam/dengan

2 Jimly Asshiddiqie, Perihal Undang-Undang (Jakarta: Rajawali Pers, 2014), 9. 
undang-undang. Atas dasar supremasi hukum, maka lembaga peradilan atau yudikatif harus memiliki independensi, karena salah satu ciri yang dianggap penting dalam setiap negara hukum yang demokratis (democratische rechsstaat) ataupun negara demokratis yang berdasar atas hukum (constitutional democracy) adalah adanya kekuasaan kehakiman yang independen dan tidak berpihak (independent and impartial). Ciri ini harus ada, apapun sistem hukum yang dipakai dalam sistem pemerintahan yang dianut, bahwa pelaksanaan the principles of independence and impartiality of the judiciary haruslah benar-benar dijamin di setiap negara demokrasi, ${ }^{3}$ karena dalam sistem hukum sebuah negara modern dicirikan oleh semacam supremasi tertentu di dalam kawasannya dan independensinya dari sistem lain yang tidak ada dalam model sederhana. ${ }^{4}$

Oleh karena itu, Jimly Asshiddiqie, menyatakan bahwa secara umum dapat dikemukakan ada dua prinsip yang sangat pokok dalam sistem peradilan, yaitu the principle of judicial independence, dan the principle if judicial impartiality. ${ }^{5}$ Meskipun dari perspektif hakim sendiri kemudian

3 Jimly Asshiddiqie, Pengantar Ilmu Hukum Tata Negara (Jakarta: Rajawali Pers, 2013), 312-313.

4 H.L.A. Hart, Konsep Hukum (Bandung: Nusa Media, 2016), 38.

5 Jimly Asshiddiqie, op.cit., 316. berkembang pemikiran prinsip lain yang juga dianggap penting seperti halnya yang tertuang dalam The Bangalore Principles of Judicial Conduct, yang memuat enam prinsip penting yang harus dijadikan pegangan bagi para hakim di dunia, yaitu prinsip independence, impartiality, integrity, propriety, equality, dan competence and diligence. ${ }^{6}$

Prinsip tersebut juga telah diadopsi dalam Undang-Undang Nomor 48 Tahun 2009 tentang Kekuasaan Kehakiman (untuk selanjutnya disebut UUKK), yang dalam salah satu konsiderannya menyatakan bahwa pembentukan UUKK tersebut untuk mewujudkan kekuasaan kehakiman yang merdeka dan peradilan yang bersih serta berwibawa perlu dilakukan penataan sistem peradilan yang terpadu.

Mahkamah Agung, menurut Sudikno Mertokusumo, memiliki lima fungsi yang diberikan baik oleh konstitusi maupun undang-undang, yaitu fungsi peradilan (justicicle functie), fungsi mengatur (regelende functie), fungsi penasihat (advieserende functie), fungsi pengawasan (toeziende functie), dan fungsi administratif (administrative functie). ${ }^{7} \quad$ Berdasarkan

6 ibid, 317.

7 Sudikno Mertokusumo, Bunga Rampai Ilmu Hukum (Yogyakarta: Liberty, 2015), edisi revisi, 187-204. 
fungsi mengatur inilah, Mahkamah Agung menerbitkan Peraturan Mahkamah Agung, salah satunya adalah Peraturan Mahkamah Agung Nomor 2 Tahun 2012 tentang Penyesuaian Batasan Tindak Pidana Ringan dan Jumlah Denda Dalam KUHP (selanjutnya disebut Perma), yang pada intinya mengubah nilai sanksi pidana denda dengan menyesuaikan pada perubahan nilai mata uang rupiah.

Perubahan nominal denda tersebut terdapat dalam dua ketentuan sebagai beikut:

1. Pasal 1:

Kata-kata "dua ratus lima puluh rupiah" dalam pasal 354, 373,379,384, 407 dan pasal 482 KUHP dibaca menjadi Rp 2.500.000,00 (dua juta lima ratus ribu rupiah).

\section{Pasal 3}

Tiap jumlah maksimum hukuman denda yang diancamkan dalam KUHP kecuali pasal 303 ayat 1 dan ayat 2, 303 bis ayat 1 dan ayat 2, dilipatgandakan menjadi 1.000 (seribu) kali.

Pertimbangan yang disampaikan oleh Mahkamah Agung dalam Penjelasan Umum Perma tersebut dilatarbelakangi penggunaan Pasal 362 KUHP oleh Penuntut Umum terhadap setiap jenis tindak pidana pencurian, padahal untuk pencurian itu sendiri dalam KUHP diuraikan kembali dalam pasal-pasal setelahnya. Mahkamah Agung menganggap bahwa penggunaan pasal tersebut untuk menyasar sanksi pidana yang lebih berat yakni paling lama 5 (lima) tahun, atau denda paling banyak Rp250,00 (dua ratus lima puluh rupiah) dengan pertimbangan bahwa barang yang dicuri memiliki nilai diatas maksimal ancaman pidana denda tersebut.

Mahkamah Agung melakukan penyesuaian nilai rupiah berdasarkan harga emas yang berlaku pada sekitar tahun 1960 . Berdasarkan informasi yang dari Museum Bank Indonesia, diperoleh harga emas murni per-1 kilogramnya senilai Rp50.510,80 (lima puluh ribu lima ratus sepuluh koma delapan puluh rupiah) atau setara dengan Rp50,51,00 (lima puluh koma lima puluh satu rupiah) per-gramnya, sedangkan harga emas per-3 Februari 2012 adalah Rp509.000,00 (lima ratus Sembilan ribu rupiah) per-gramnya, sehingga kenaikan nilai rupiah tersebut dikalikan 10.000 (sepuluh ribu) kali.

Secara kedudukan, Mahkamah Agung merupakan lembaga negara yang sejajar 
dengan Presiden, ${ }^{8}$ yang dapat disebut sebagai lembaga tinggi negara, karena Indonesia menganut separation of power yang memisahkan kekuasaan eksekutif dengan yudikatif, meskipun saat ini tidak ada lagi sebutan lembaga tinggi dan lembaga tertinggi negara. ${ }^{9}$ Meskipun Mahkamah Agung memiliki fungsi mengatur, kekuasaan untuk membentuk undangundang tetap berada pada Legislatif, yakni Dewan Perwakilan Rakyat (DPR), yang dibahas dan disetujui bersama dengan Presiden. ${ }^{10}$ Untuk itu, materi muatan yang seharusnya diatur dalam undang-undang, tidak dapat diatur dalam peraturan di bawah undang-undang, sehingga Mahkamah Agung tidak dapat menerbitkan Perma yang berisi materi muatan undang-undang.

\section{B. Perumusan Masalah}

Penulis merumuskan permasalahan yang akan dibahas dalam tulisan ini sebagai berikut:

1. Apakah Peraturan Mahkamah Agung Nomor 2 Tahun 2012 tentang Penyesuaian Batasan Tindak Pidana Ringan dan Jumlah Denda Dalam KUHP merupakan penemuan hukum?

8 Lihat Pasal 24 UUD NRI Tahun 1945.

9 Penyebutan lembaga tinggi untuk menyederhanakan pemahaman, karena konstitusi tidak lagi mengenali lembaga tinggi dan lembaga tertinggi negara. Lihat Jimmly Asshiddiqie,
2. Apakah materi muatan Peraturan Mahkamah Agung Nomor 2 Tahun 2012 tentang Penyesuaian Batasan Tindak Pidana Ringan dan Jumlah Denda Dalam KUHP sudah tepat sesuai dengan ketentuan pembentukan peraturan perundang-undangan?

\section{Pembahasan}

\section{A. Prinsip Penemuan Hukum}

Penemuan hukum selalu dibutuhkan ketika hukum berhadapan dengan peristiwa hukum konkret. Apa yang dimaksud dengan penemuan hukum lazimnya adalah proses pembentukan hukum oleh hakim, atau aparat hukum lainnya yang ditugaskan untuk penerapan peraturan umum pada peristiwa hukum konkret. Lebih lanjut, Sudikno Mertokusumo menyatakan bahwa penemuan hukum adalah proses konkretisasi atau individualisasi peraturan hukum (das Sollen) yang bersifat umum dengan mengingat akan peristiwa konkret (das Sein) tertentu. ${ }^{11}$

Definisi ini tidak jauh berbeda dengan yang dikemukakan oleh Loudoe, bahwa penemuan hukum bukan suatu proses yang logis belaka melalui subsumpsi dari fakta

Penguatan Sistem Pemerintahan dan Peradilan (Jakarta: Sinar Grafika, 2015), 101.

${ }^{10}$ Lihat Pasal 20 UUD NRI Tahun 1945.

11 Sudikno Mertokusumo, Penemuan Hukum (Yogyakarta: Liberty, 2009), 37. 
pada ketentuan undang-undang, akan tetapi adalah juga penilaian dari fakta untuk kemudian menemukan hukumnya. ${ }^{12}$ Sedangkan menurut J.A. Pontier, penemuan hukum adalah sebuah reaksi terhadap situasi problematik yang dipaparkan orang dalam peristilahan hukum. Penemuan hukum diarahkan pada pemberian jawaban atas pertanyaan tentang hukum yang ditimbulkan oleh kejadian konkret. $^{13}$

Dinyatakan oleh Paul Scholten, het rechts is er, doch het moet worden gevoden, yang pada intinya menyatakan bahwa hukum itu ada, tetapi masih harus ditemukan. Scholten, sebagaimana dikutip oleh Eddy O.S. Hiariej, juga menyatakan adalah sesuatu yang khayal apabila beranggapan bahwa undang-undang itu telah mengatur segalanya secara tuntas. ${ }^{14}$

Lebih lanjut, Satjipto Rahardjo, seperti dikutip oleh Eddy O.S. Hiariej dari Anthon Freddy Susanto, menyatakan bahwa penemuan hukum berbeda dengan penerapan hukum. Dalam penemuan hukum ditemukan sesuatu yang baru yang dapat

12 John Z. Loudoe, Menemukan Hukum Melalui Tafsir dan Fakta (Jakarta: Bina Aksara, 1985), V, sebagaimana dikutip dalam Eddy O.S. Hiariej, Asas Legalitas dan Penemuan Hukum dalam Hukum Pidana (Jakarta: Erlangga, 2016), 56.

${ }^{13}$ J.A. Pontier, Penemuan Hukum (Bandung: Jendela Mas Pustaka, 2008), 1, sebagaimana dikutip dalam Eddy O.S. Hiariej, ibid. dilakukan, baik lewat penafsiran, analogi, maupun penghalusan hukum. Penegakan hukum tidak hanya dilakukan dengan logika penerapan hukum yang mengandalkan penggunaan logika, melainkan melibatkan penilaian dan memasuki ranah pemberian makna. ${ }^{15}$

\section{Berdasarkan hal tersebut, Eddy O.S.}

Hiariej menyatakan bahwa setidaknya terdapat dua unsur penting dalam penemuan hukum. Pertama, hukum atau sumber hukum, dan kedua, adalah fakta. ${ }^{16}$ Unsur hukum atau sumber hukum dalam penemuan hukum adalah undang-undang. Hal ini berkaitan dengan suatu postulat yang dikenal dengan istilah De wet is onschendbaar (undang-undang tidak dapat diganggu gugat), meskipun tidak semua hukum ditemukan dalam undang-undang. Oleh karena itu, unsur hukum/sumber hukum dalam penemuan hukum tidak hanya meliputi undang-undang semata, tetapi meliputi juga doktrin, yurisprudensi, perjanjian, dan kebiasaan. ${ }^{17}$ Untuk melakukan penemuan hukum, maka penguasaan atas sumber hukum tersebut

\footnotetext{
${ }^{14}$ Eddy O.S. Hiariej, ibid, 55.

${ }^{15}$ ibid.

16 ibid, 56.

17 J.A. Pontier, Penemuan Hukum..., sebagaimana dikutip dalam Eddy O.S. Hiariej, ibid, 56.
} 
tidak kalah pentingnya dengan penguasaan atas konsep, teori, atau analisis hukum. ${ }^{18}$

Fakta sebagai unsur penemuan hukum adalah penilaian terhadap fakta yang berdasarkan hukum, yakni situasi faktual sebagai penemuan suatu kebenaran, kemudian situasi faktual itu dapat dipandang sebagai relevan secara yuridis, seleksi dan kualifikasi atas fakta-fakta. ${ }^{19}$

Berdasarkan hal tersebut, pada prinsipnya penemuan hukum merupakan proses konkretisasi peraturan hukum, dalam hal ini undang-undang, yang bersifat umum ke dalam peristiwa konkret. Apabila terjadi kekosongan hukum, sedangkan undangundang tidak mengatur penyelesaian persoalan hukum, maka hakim dalam kewenangannya melakukan penafsiran hukum untuk mengisi kekosongan hukum dalam rangka penyelesaian masalah hukum. ${ }^{20}$

Menurut Sudikno Mertokusumo, dikenal adanya aliran penemuan hukum konservatif dan aliran penemuan hukum progresif. Aliran penemuan hukum progresif berpendapat bahwa hukum dan

18 Bagir Manan, Konvensi Ketatanegaraan (Yogyakarta: UII Press, 2006), 27.

19 J.A. Pontier, Penemuan Hukum..., sebagaimana dikutip dalam Eddy O.S. Hiariej, op.cit., 57.

${ }^{20}$ Teguh Prasetyo dan Abdul Hakim B., Ilmu Hukum dan Filsafat Hukum (Yogyakarta: Pustaka Pelajar, 2007), 35, sebagaimana dikutip dalam J. Pajar peradilan merupakan alat untuk perubahan sosial (social engineering), sedangkan aliran penemuan hukum konservatif berpendapat bahwa hukum dan peradilan itu hanyalah untuk mencegah kemerosotan moral dan nilai-nilai lain. Masih menurut aliran penemuan hukum konservatif, kinerja hakim sepenuhnya tunduk pada teks undang-undang, hakim hanya mengkonstatir (menetapkan) bahwa undang-undang dapat diterapkan pada peristiwa hukum konkret. ${ }^{21}$

Terdapat 4 (empat) pengelompokan metode penemuan hukum, sebagaimana disampaikan oleh Sudikno Mertokusumo, yakni interpretasi (penafsiran); argumentasi; penyempitan hukum (rechtsverfijning); dan penemuan hukum bebas (metode eksposisi). Keempat metode tersebut apabila diuraikan menjadi sebagai berikut: ${ }^{22}$

1. Interpretasi (Penafsiran)
a. Interpretasi gramatikal
b. Interpretasi sistematis atau logis
c. Interpretasi Historis
d. Interpretasi Teleologis atau Sosiologis

Widodo, Menjadi Hakim Progresif (Bandar Lampung: Indepth Publishing, 2013), 55.

21 Sudikno Mertokusumo, Bab-bab tentang Penemuan Hukum (Bandung: Citra Aditya Bakti, 1993), 6, sebagaimana dikutip dalam J. Pajar Widodo, ibid, 65.

${ }^{22}$ Sudikno Mertokusumo, Penemuan Hukum, op.cit., 57-78. 
e. Interpretasi Komparatif

f. Interpretasi Antisipatif atau Futuristis

g. Interpretasi Restriktif

h. Interpretasi Ekstensif

2. Argumentasi
a. Argumentum Per Analogiam (Analogi)

b. Argumentum a Contrario (a contrario)

3. Penyempitan

Hukum (Rechtsverfijning)

4. Penemuan Hukum Bebas (Metode Eksposisi)
a. Sinomisasi
b. Terjemahan
c. Antitese
d. Restriksi
e. Ampliasi
f. Paraleli
g. Deskripsi
h. Enumerasi
i. Archetipasi
j. Ilustrasi
k. Eksemplifikasi

\section{B. Penemuan Hukum dan Hak Menguji oleh Hakim}

Permasalahan dalam penemuan hukum pada umumnya dipusatkan sekitar

\footnotetext{
${ }^{23}$ Sudikno Mertokusumo, op.cit., 38.
}

hakim dan pembentuk undang-undang. Akan tetapi dalam kenyataannya permasalahan penemuan hukum ini tidak hanya berperan pada kegiatan hakim dan pembentuk undang-undang saja. Bisa dikatakan bahwa penemuan hukum merupakan permasalahan setiap pencari keadilan.

Hasil penemuan hukum oleh hakim merupakan hukum karena mempunyai kekuatan mengikat sebagai hukum karena dituangkan dalam bentuk putusan, sehingga hasil penemuan hukum oleh hakim juga termasuk sumber hukum. ${ }^{23}$ Perbedaannya, bila hakim dibenturkan dengan bagaimana pemecahan peristiwa hukum yang konkret atau terjadi saat itu, maka yang dihadapi pembentuk undang-undang merupakan bagaimana pemecahan peristiwa hukum yang akan atau besar kemungkinan terjadi di waktu mendatang, sehingga sifatnya adalah preskriptif. Hasil penemuan hukum oleh pembentuk undang-undang juga merupakan hukum karena mempunyai kekuatan mengikat sebagai hukum karena dituangkan dalam bentuk undang-undang sekaligus merupakan sumber hukum. ${ }^{24}$

Konsep kuno menempatkan hakim sebagai corong/terompet undang-undang saja (la bouche de la loi), sehingga menutup

${ }^{24}$ ibid., 39. 
ruang untuk penemuan hukum, tidak menghasilkan hukum yang responsif. Dalam perkembangannya kini, hukum diharapkan dapat memberikan keadilan substantif, sekaligus keadilan prosedural.

Sebagaimana telah diuraikan sebelumnya, bahwa untuk melakukan penemuan hukum terdapat beberapa metode. Namun, secara prinsip penemuan hukum juga dapat dilakukan oleh hakim, apapun metode yang digunakan. Hanya saja konkretisasi peristiwa hukum oleh hakim dibatasi sebatas dimuat dalam putusan. Hal ini dikarenakan penemuan hukum oleh hakim merupakan tugas hakim dalam persidangan yang dimulai dengan mengkonstatasi peristiwa konkret, mengkualifikasi peristiwa konkret menjadi peristiwa hukum, dan pada akhirnya menjatuhkan putusan dengan menerapkan aturan hukum terhadap peristiwa hukum tersebut. ${ }^{25}$ Pada dasarnya hal tersebut tidak berbeda dengan kegiatan sarjana hukum dalam menghadapi suatu konflik atau kasus yang harus dipecahkan, yakni legal problem identification, legal problem solving, dan decision making. Setiap sarjana hukum, terutama hakim, selalu dihadapkan peristiwa

${ }^{25}$ Eddy O.S. Hiariej, op.cit., 84.

${ }^{26}$ Sudikno Mertokusumo, Penemuan Hukum, op.cit., 79.

27 Oliver Wendell Holmes, The Common Law, (Boston: Little, Brown and Company, 1963), konkret yang harus dicarikan hukumnya atau dipecahkan untuk diselesaikan. ${ }^{26}$

Selain metode berfikir silogisme semata, sebagaimana yang digunakan dalam sistem klasik, menurut Holmes, ${ }^{27}$ seorang hakim dalam mengambil putusan hukum atau berfikir, seharusnya berusaha mendapat masukan yang luas berupa:

1. The felt necessities of the time;

2. The prevalent moral and political theories;

3. Intuitions of public policy, avowed or unconscious;

4. (even) the prejudices which judges share with theirfellow-men.

Pendapat tersebut didasarkan bahwa sistem klasik masih mempersempit ruang penemuan hukum oleh hakim, sehingga perlu menggunakan sistem materiil yuridis yang tidak semata berfikir logis dan silogistis semata. Pelaksanaan hukum oleh hakim tidak hanya masalah logika murni dan penggunaan ratio yang tepat, tetapi lebih merupakan masalah pemberian bentuk yuridis pada asas-asas hukum materiil yang menurut sifatnya tidak logis dan tidak mendasarkan pada pikiran yang abstrak

sebagaimana dikutip dalam Satjipto Rahardjo, Lapisan-lapisan dalam Studi Hukum, (Malang: Bayumedia, 2009), 99. 
tetapi lebih pada pengalaman dan penilaian yuridis.

Hakim atau para hakim harus menetapkan pilihan atas salah satu alternatif yang paling sesuai dengan struktur kasus, untuk akhirnya diformulasikan sebagai putusan (termasuk juga yang lazim disebut penetapan). Pertimbangan inilah yang kemudian melatarbelakangi dissenting opinion dan concurring opinion hakim tercantum dalam putusan. Istilah putusan secara teknis dibedakan dengan penetapan karena yang pertama mengacu pada produk peradilan contentieus, sementara yang kedua produk peradilan voluntair. ${ }^{28}$ Putusan hakim per-definisi adalah suatu pernyataan yang oleh hakim, sebagai pejabat negara yang diberi wewenang untuk itu, diucapkan di persidangan dan bertujuan untuk mengakhiri atau menyelesaikan suatu perkara atau sengketa antara para pihak. Dalam praktik, semua putusan selalu dibacakan (uitspraak) berdasarkan naskah tertulis yang telah dipersiapkan. Dalam hukum acara di Indonesia, misalnya, dianut pendapat bahwa apabila ada perbedaan antara naskah tertulis dan ucapan lisan pada saat naskah putusan dibacakan, maka yang dijadikan pegangan adalah ucapan lisan

28 Arief Hidayat, "Penemuan Hukum melalui Penafsiran Hakim dalam Putusan Pengadilan", Pandecta, Volume 8, Nomor 2 (Juli 2013): 156.
(Surat Edaran Mahkamah Agung No. 5 Tahun 1959 dan No. 1 Tahun 1962).

Selain memiliki kewenangan penemuan hukum, hakim juga memiliki hak menguji (toetsingsrecht). Dalam praktik di Indonesia, hak menguji tersebut berada pada Mahkamah Konstitusi, untuk menguji undang-undang terhadap Undang Undang Dasar Negara Republik Indonesia Tahun 1945 (selanjutnya disebut UUD NRI Tahun 1945), dan Mahkamah Agung, untuk menguji peraturan perundang-undangan di bawah undang-undang terhadap undangundang. ${ }^{29}$

Hak menguji tersebut terdiri dari hak menguji formal dan hak menguji material. Hak menguji formal adalah wewenang untuk menilai, apakah suatu produk peraturan perundang-undangan telah dibentuk sesuai dengan prosedur yang telah diatur dalam undang-undang. Pengujian formal biasanya terkait soal-soal prosedural dan legalitas kompetensi institusi pembuatnya. Hak menguji material adalah wewenang untuk menyelidiki dan menilai apakah suatu peraturan perundangundangan isinya sesuai atau bertentangan dengan peraturan perundang-undangan yang derajatnya lebih tinggi, serta apakah suatu

\footnotetext{
${ }^{29}$ Lihat Pasal 24A ayat (1) dan Pasal 24C ayat (1) UUD NRI Tahun 1945.
} 
kekuasaan tertentu (verordenende macht) berhak mengeluarkan suatu peraturan tertentu. ${ }^{30}$ Pengujian material berkaitan dengan kemungkinan pertentangan materi suatu peraturan perundang-undangan dengan peraturan perundang-undangan yang lebih tinggi, atau menyangkut kekhususan yang dimiliki suatu aturan dibanding dengan norma yang berlaku umum.

\section{Materi Muatan dan Perubahan Undang-Undang}

Apabila melihat hubungan hukum dengan kekuasaan, maka yang dapat memberikan atau memaksakan sanksi terhadap pelanggaran kaidah hukum adalah penguasa, karena penegakan hukum dalam hal ada pelanggaran adalah monopoli penguasa, demikian dinyatakan oleh Sudikno Mertokusumo. ${ }^{31}$ Lebih lanjut, Sudikno menyatakan bahwa hakikat kekuasaan tidak lain adalah kemampuan seseorang untuk memaksakan kehendaknya kepada orang lain. Hukum ada karena kekuasaan yang sah. Kekuasaan yang sahlah yang menciptakan hukum. Ketentuan yang

30 Sri Soemantri, Hak Uji Material di Indonesia, (Bandung: Alumni, 1997), 11, sebagaimana dikutip dalam Fatmawati, Hak Menguji (Toetsingsrecht) yang dimiliki Hakim dalam Sistem Hukum Indonesia, (Jakarta; RajaGrafindo, 2005), 93.

31 Sudikno Mertokusumo, Mengenal Hukum, (Yogyakarta: Cahaya Atma Pustaka, 2016), 25. tidak berdasarkan kekuasaan yang sah pada dasarnya bukanlah hukum. Jadi, hukum bersumber pada kekuasaan yang sah. ${ }^{32}$

Konstitusi berupa UUD NRI Tahun 1945, merupakan Staatgrundgesetz atau aturan dasar negara yang memberikan kekuasaan pembentukan undang-undang kepada DPR yang membahas untuk mendapat persetujuan bersama dengan Presiden, sehingga undang-undang dikatakan sah dan memiliki kekuatan hukum apabila telah disetujui bersama oleh DPR dan Presiden. ${ }^{33}$

Cara menemukan materi muatan undang-undang, menurut Hamid $\mathbf{S}$. Attamimi, dapat dilakukan melalui: ${ }^{34}$

1. Ketentuan dalam UUD NRI Tahun 1945 ;

2. Berdasarkan wawasan negara berdasarkan atas hukum (rechsstaat); dan

3. Berdasarkan wawasan pemerintahan berdasarkan sistem kostitusi.

Apabila dilihat dalam ketentuan UUD NRI Tahun 1945, maka akan kita temukan sebanyak 43 (empat puluh tiga) hal yang diperintahkan secara tegas untuk diatur dengan undang-undang, ${ }^{35}$ dan apabila

32 ibid.

${ }^{33}$ Lihat Pasal 20 UUD NRI Tahun 1945.

${ }^{34}$ Maria Farida Indrati S., Ilmu Perundangundangan, jilid I, (Yogykarta: Kanisius, 2017), 246.

35 Frase yang digunakan dalam UUD NRI Tahun 1945 beragam, ada yang "diatur lebih lanjut dengan", “diatur dengan", “diatur dalam”, dan 
dilakukan pengelompokkan, meskipun pembagian tersebut tidak dapat dibedakan secara tegas, pembagian tersebut sebagai berikut: ${ }^{36}$

1. Kelompok lembaga negara:

Pasal 2 ayat (1), Pasal 6 ayat (2), Pasal 6A ayat (5), Pasal 19 ayat (2), Pasal 20A ayat (4), Pasal 22B, Pasal 22C ayat (4), Pasal 22D ayat (4), Pasal 23G ayat (2), Pasal 24 ayat (3), Pasal 24A ayat (5), Pasal 24B ayat (4), Pasal 24C ayat (6), dan Pasal 25.

2. Kelompok penetapan organisasi dan alat kelengkapan negara:

Pasal 16, Pasal 17 ayat (4), Pasal 18 ayat (1), Pasal 18 ayat (7), Pasal 18A ayat (1), Pasal 23 ayat (4), Pasal 23 ayat (5), dan Pasal 23D.

3. Kelompok hak-hak (asasi) manusia: Pasal 12, Pasal 15, Pasal 18A ayat (2), Pasal 18B ayat (1), Pasal 18B ayat (2), Pasal 22E ayat (6), Pasal 23 ayat (1), Pasal 23A, Pasal 23B, Pasal 23C, Pasal 23E ayat (3), Pasal 26 ayat (1), Pasal 26 ayat (3), Pasal 28, Pasal 28I ayat (5), Pasal 30 ayat (5), Pasal 31 ayat (3), Pasal 33 ayat (5), dan Pasal 34 ayat (4).

“ditetapkan dengan". Meskipun pemaknaan "diatur dengan" diartikan bahwa ketentuan tersebut dapat berada dalam undang-undang tersendiri, tetapi dalam praktiknya dapat pula
4. Kelompok pengaturan wilayah negara:

\section{Pasal 25A}

5. Kelompok pengaturan atribut negara: Pasal 36C

6. Kelompok lain-lain:

Pasal 11 ayat (3), dan Pasal 22A

Apabila materi muatan undangundang dilihat berdasarkan wawasan negara berdasarkan atas hukum (rechsstaat), maka Indonesia termasuk dalam negara berdasar atas hukum (rechsstaat) material/sosial, ${ }^{37}$ hal ini dapat ditemukan dalam Pembukaan UUD NRI Tahun 1945 alinea ke-4 yang menyebutkan:

“... untuk membentuk suatu pemerintahan negara Indonesia yang melindungi segenap bangsa Indonesia dan seluruh tumpah darah Indonesia dan untuk memajukan kesejahteraan umum, mencerdaskan kehidupan bangsa, dan ikut melaksanakan ketertiban dunia yang berdasarkan kemerdekaan, perdamaian abadi, dan keadilan sosial ..."

Adapun yang dimaksud dengan negara berdasar atas hukum (rechsstaat) material/sosial, adalah negara berdasar atas

digabungkan dengan materi muatan lain dalam satu undang-undang.

36 Maria Farida Indrati S., op.cit., 247.

37 ibid., 241. 


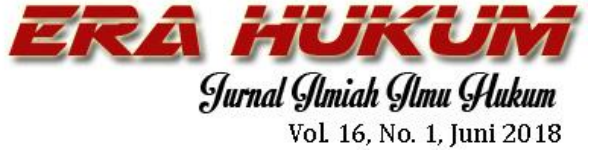

hukum modern yang sering juga disebut welfare state atau verzorgingstaat. Dalam wawasan negara hukum ini, keketatan sudah lebih dilonggarkan dengan pengakuan terhadap adanya kebijaksanaan (freies ermesson) bagi tindakan pemerintahan negara meskipun dengan disertai imbangan dalam bentuk peradilan administrasi. ${ }^{38}$ Dalam negara berdasar atas hukum material ini negara berkewajiban menyelenggarakan kesejahteraan rakyat, sehingga campur tangan pemerintah dalam mengurusi kepentingan ekonomi rakyat, kepentingan politik dan sosial, kepentingan budaya dan lingkungan hidupnya serta masalah-masalah lainnya tidak dapat dielakkan. Maria Farida Indrati S., dalam bukunya Ilmu Perundang-undangan, menyatakan bahwa ciri-ciri dari rechsstaat material/sosial ini ditandai dengan: ${ }^{39}$

1. prinsip perlindungan hak asasi manusia;

2. prinsip pemisahan pembagian kekuasaan;

3. prinsip pemerintahan berdasar undangundang;

4. prinsip peradilan administrasi; dan

5. prinsip pemerintahan yang menciptakan kemakmuran rakyat.

38 ibid., 240.

39 ibid.

40 Bagir Manan, Dasar-dasar Perundang-undangan Indonesia, (Jakarta, Ind Hill Co, 1992), 37, sebagaimana dikutip dalam Bayu Dwi Anggono,
Wawasan pemerintahan berdasar sistem konstitusi merupakan pasangan dari wawasan negara berdasarkan atas hukum (rechsstaat). Dalam wawasan ini, kewenangan pemerintah beserta segala tindakannya dalam menjalankan tugas dibatasi oleh konstitusi. Hal ini sejalan dengan pendapat Bagir Manan, bahwa tolok ukur menentukan materi muatan undang-undang umumnya sebagai berikut: ${ }^{40}$

1. ditetapkan dalam Undang-Undang Dasar;

2. ditetapkan dalam undang-undang terdahulu;

3. ditetapkan dalam rangka mencabut, menambah, atau mengganti undangundang yang lama;

4. materi muatan menyangkut hak dasar atau hak asasi; dan

5. materi muatan menyangkut kepentingan atau kewajiban rakyat banyak.

Terkait materi muatan undangundang, Jimly Asshiddiqie berpendapat: ${ }^{41}$

"Terdapat 3 (tiga) hal penting yang harus diatur oleh para wakil rakyat melalui parlemen, yaitu:

1. pengaturan yang dapat mengurangi hak dan kebebasan warga negara;

Perkembangan Pembentukan Undang-Undang di Indonesia, (Jakarta, Konstitusi Press, 2014), 65.

41 Jimly Asshiddiqie, Pokok-pokok Hukum Tata Negara Indonesia Pasca Reformasi, (Jakarta: Bhuana Ilmu Populer, 2007), 161, sebagaimana dikutip dalam Bayu Dwi Anggono, ibid. 


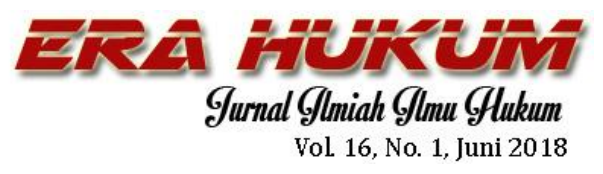

2. pengaturan yang dapat membebani harta kekayaan warga negara; dan

3. pengaturan mengenai pengeluaranpengeluaran oleh penyelenggara negara.

Pengaturan mengenai ketiga hal tersebut hanya dapat dilakukan atas persetujuan dari warga negara sendiri, yaitu melalui perantaraan wakil-wakil mereka di parlemen sebagai lembaga perwakilan rakyat."

Oleh karena Indonesia menganut adanya wawasan pemerintahan berdasar sistem konstitusi, maka kekuasaan perundang-undangan terikat oleh UUD NRI Tahun 1945, sedangkan kekuasaan pemerintahan dan kekuasaan peradilan terikat oleh undang-undang dan hukum negara, dalam hal ini maka materi muatan undang-undang dibatasi dalam Pasal 10 ayat (1) Undang-Undang Nomor 12 Tahun 2011 tentang Pembentukan Peraturan Perundangundangan, sebagai berikut:

Pasal 10

(1) Materi muatan yang harus diatur dengan undang-undang berisi:

a. pengaturan lebih lanjut mengenai ketentuan Undang Undang Dasar

${ }^{42}$ Lihat Pasal 15 Undang-Undang Nomor 12 Tahun 2011.
Negara Republik Indonesia

Tahun 1945;

b. perintah suatu undangundang untuk diatur dengan undang-undang;

c. pengesahan perjanjian internasional tertentu;

d. tindak lanjut atas putusan Mahkamah Konstitusi; dan/atau

e. pemenuhan kebutuhan hukum dalam masyarakat.

Selain itu, Undang-Undang Nomor 12 Tahun 2011 juga menegaskan bahwa materi muatan mengenai ketentuan pidana hanya dapat dimuat dalam undang-undang, peraturan daerah provinsi dan peraturan daerah kabupaten/kota. ${ }^{42}$ Batasan materi muatan undang-undang tersebut, termasuk untuk melakukan perubahan undangundang. Perubahan suatu undang-undang dilakukan apabila terdapat ketentuan yang tidak sesuai lagi dengan situasi atau kondisi yang berlaku dalam masyarakat. Perubahan tersebut dapat meliputi hal sebagai berikut: ${ }^{43}$ 1. menambah atau menyisipkan ketentuan baru, menyempurnakan atau menghapus ketentuan yang sudah ada, baik yang berbentuk Bab, Bagian,

${ }^{43}$ Maria Farida Indrati S., Ilmu Perundangundangan, jilid II, (Yogyakarta: Kanisius, 2017), 179. 
Paragraph, Pasal, ayat, maupun perkataan, angka, huruf, tanda baca, dan lain sebagainya;

2. mengganti suatu ketentuan dengan ketentuan lain, baik berbentuk Bab, Bagian, Paragraph, Pasal, ayat, maupun perkataan, angka, huruf, tanda baca, dan lain sebagainya.

Hal yang harus diperhatikan dalam melakukan perubahan peraturan perundangundangan (termasuk undang-undang), menurut Maria Farida Indrati S., sebagai berikut: ${ }^{44}$

1. perubahan suatu peraturan perundangundangan dilakukan oleh pejabat yang berwenang membentuknya, berdasarkan pada prosedur yang berlaku, dan dengan suatu peraturan perundang-undangan yang sejenis (atau setingkat);

2. perubahan suatu peraturan perundangundangan diharapkan dilakukan secara baik tanpa mengubah sistematika dari peraturan perundang-undangan yang diubah;

3. dalam suatu peraturan perubahan, perumusan judul hendaknya disebut peraturan perundang-undangan mana yang diubah dan untuk perubahan yang kedua kali dan selanjutnya, disebutkan

44 ibid., 180. Lihat juga ketentuan dalam Lampiran II Undang-Undang Nomor 12 Tahun 2011 tentang Pembentukan Peraturan Perundang-undangan. 
peraturan perundang-undangan secara besar-besaran, maka demi kepentingan pemakai peraturan perundang-undangan tersebut dipandang lebih baik apabila dibentuk peraturan perundang-undangan yang baru.

Peraturan perundang-undangan di bawah undang-undang yang diakui di Indonesia, pada prinsipnya sebagai peraturan pelaksanaan (verordung) atau peraturan otonom (autonome satzung). Perbedaannya berada pada darimana asal kewenangan pembentukkannya, apabila peraturan pelaksanaan bersumber dari kewenangan delegasi, peraturan otonom bersumber dari kewenangan atribusi. ${ }^{45}$

Atribusi kewenangan dalam pembentukan peraturan perundangundangan (attributie van wetgevingsbevoegdheid) ialah pemberian kewenangan membentuk peraturan perundang-undangan yang diberikan oleh undang-undang dasar (grondwet) atau dari undang-undang (wet) kepada suatu lembaga negara atau pemerintahan. ${ }^{46}$ Kewenangan tersebut melekat terus menerus dan dapat dilaksanakan atas prakarsa sendiri setiap waktu diperlukan, sesuai batas-batas yang diberikan.

$$
\text { Delegasi kewenangan dalam }
$$

pembentukan peraturan perundangundangan (delegatie van wetgevingsbevoegdheid) ialah pelimpahan kewenangan membentuk peraturan perundang-undangan yang dilakukan oleh peraturan perundang-undangan yang lebih tinggi kepada peraturan perundangundangan yang lebih rendah, baik pelimpahan dinyatakan dengan tegas maupun tidak. Berlainan dengan kewenangan atribusi, pada kewenangan delegasi, tidak memberikan kewenangan tersebut, melainkan "mewakilkan" dan selain itu kewenangan delegasi ini bersifat sementara dalam arti kewenangan ini dapat diselenggarakan sepanjang pelimpahan tersebut masih ada. ${ }^{47}$

Artinya, keabsahan proses pembentukan peraturan perundangundangan di bawah undang-undang haruslah didasarkan atas legislative delegation of rule-making power dari pembentuk undang-undang kepada pembentuk peraturan yang dimaksud. ${ }^{48}$

1988), 57, sebagaimana dikutip dalam Maria Farida Indrati S., ibid.

47 ibid, 56.

48 Jimly Asshiddiqie, Perihal Undang-Undang, op.cit., 271. 


\section{Sejarah Perubahan KUHP}

KUHP yang berlaku di Indonesia sampai saat ini memang peninggalan kolonial, sehingga terdapat beberapa ketentuan yang perlu disesuaikan dengan kondisi yang berkembang. Sejak Indonesia merdeka, selain Perma sebagaimana telah disampaikan sebelumnya, tercatat telah dilakukan perubahan terhadap KUHP sebanyak 11 (sebelas) kali amandemen melalui undang-undang yang materi muatannya khusus untuk perubahan KUHP, 2 (dua) kali melalui Putusan Mahkamah Konstitusi, dan 4 (empat) kali melalui undang-undang yang bermuatan pidana khusus. Perubahan tersebut dapat dirinci sebagai berikut:

\section{Amandemen:}

\begin{tabular}{|c|c|c|}
\hline No & Bentuk & Substansi \\
\hline a. & $\begin{array}{l}\text { UU No. } 1 \\
\text { Tahun } 1946\end{array}$ & $\begin{array}{l}\text { 1) menyatakan ketentuan } \\
\text { KUHP menjadi tidak } \\
\text { berlaku apabila memenuhi } \\
\text { kriteria sebagai berikut: } \\
\text { (Pasal V) } \\
\text { a) seluruh } \\
\text { sebagiannya tidak dapat } \\
\text { dijalankan; } \\
\text { b) bertentangan dengan } \\
\text { Indonesia; dan } \\
\text { c) tidak mempunyai arti } \\
\text { lagi. } \\
\text { 2) menambahkan ketentuan } \\
\text { baru (kriminalisasi), terkait } \\
\text { penyebaran kabar atau } \\
\text { berita bohong. (Pasal IX- } \\
\text { Pasal XVI) }\end{array}$ \\
\hline
\end{tabular}

\begin{tabular}{|c|c|c|}
\hline No & Bentuk & Substansi \\
\hline b. & $\begin{array}{l}\text { UU No. } 20 \\
\text { Tahun } 1946\end{array}$ & $\begin{array}{l}\text { Mengubah Pasal } 10 \text { dengan } \\
\text { menambahkan satu jenis pidana } \\
\text { pokok yakni Pidana Tutupan. }\end{array}$ \\
\hline c. & $\begin{array}{l}\text { UU No. } 73 \\
\text { Tahun } 1958\end{array}$ & 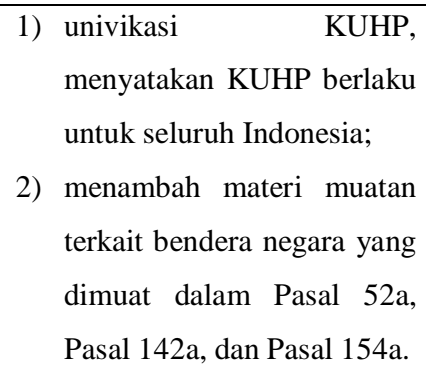 \\
\hline d. & $\begin{array}{ll}\text { UU No. } & 1 \\
\text { Tahun } & 1960\end{array}$ & $\begin{array}{l}\text { Memperberat ancaman pidana } \\
\text { pada Pasal } 188 \text {, Pasal } 359 \text {, dan } \\
\text { Pasal } 360 .\end{array}$ \\
\hline e. & $\begin{array}{ll}\text { UU No. } & 16 \\
\text { PRP } & 1960\end{array}$ & $\begin{array}{l}\text { Mengubah Pidana Denda untuk } \\
\text { kejahatan ringan semula } \\
\text { Rp25,00 menjadi Rp250,00 }\end{array}$ \\
\hline f. & $\begin{array}{lrl}\text { UU } & \text { No. } & 18 \\
\text { PRP } & 1960 & \end{array}$ & $\begin{array}{l}\text { 1) mengubah mata uang dalam } \\
\text { KUHP semula gulden } \\
\text { menjadi rupiah; } \\
\text { 2) memperberat seluruh } \\
\text { ancaman pidana denda } \\
\text { dengan dikalikan } 15 .\end{array}$ \\
\hline g. & $\begin{array}{lll}\text { UU } & \text { No. } & 2 \\
\text { PNPS } & 1964\end{array}$ & $\begin{array}{l}\text { Mengubah pelaksanaan Pidana } \\
\text { Mati, semula digantung menjadi } \\
\text { ditembak mati. }\end{array}$ \\
\hline h. & $\begin{array}{lll}\text { UU } & \text { No. } & 1 \\
\text { PNPS } & 1965\end{array}$ & $\begin{array}{l}\text { Menambah satu pasal, yakni } \\
\text { Pasal 156a yang memuat } \\
\text { ketentuan terkait delik agama. }\end{array}$ \\
\hline i. & $\begin{array}{l}\text { UU No. } 7 \\
\text { Tahun } 1974\end{array}$ & $\begin{array}{l}\text { 1) } \begin{array}{l}\text { mengubah } \\
\text { dengan }\end{array} \text { memperberat } \\
\text { ancaman pidana penjara } \\
\text { menjadi } 10 \text { tahun dan } \\
\text { pidana denda menjadi } \\
\text { Rp25.000.000,00; } \\
\text { 2) mengubah Pasal 542, } \\
\text { semula pelanggaran, } \\
\text { menjadi kejahatan; } \\
\text { 3) menambah satu pasal, yakni } \\
\text { Pasal 303bis, yang memuat } \\
\text { ancaman pidana penjara } \\
\text { menjadi } 10 \text { tahun dan }\end{array}$ \\
\hline
\end{tabular}




\begin{tabular}{|c|c|c|}
\hline No & Bentuk & Substansi \\
\hline & & $\begin{array}{llr}\text { pidana denda } & \text { menjadi } \\
\text { Rp25.000.000,00 } & \text { bagi } \\
\text { pelaku judi, } & \text { sekaligus } \\
\text { mencabut Pasal 542. }\end{array}$ \\
\hline j. & $\begin{array}{l}\text { UU No. } 4 \\
\text { Tahun } 1976\end{array}$ & $\begin{array}{l}\text { Menambah materi muatan } \\
\text { terkait Kejahatan Penerbangan, } \\
\text { yang dimuat dalam Pasal 479a- } \\
\text { Pasal 479f. }\end{array}$ \\
\hline $\mathrm{k}$. & $\begin{array}{l}\text { UU No. } 27 \\
\text { Tahun } 1999\end{array}$ & $\begin{array}{l}\text { Menambahkan materi muatan } \\
\text { terkait Penyebaran Ajaran } \\
\text { Terlarang } \\
\text { Leninisme, dan Komunisme), } \\
\text { yang dimuat dalam Pasal 107a- } \\
\text { Pasal 107f. }\end{array}$ \\
\hline
\end{tabular}

Tabel 1.

Perubahan KUHP melalui Undang-Undang khusus mengubah KUHP.

\section{Putusan Mahkamah Konstitusi}

\begin{tabular}{|l|l|lr|}
\hline No & \multicolumn{1}{|c|}{ Putusan } & \multicolumn{1}{|c|}{ Substansi } \\
\hline a. & 013- & $\begin{array}{l}\text { Menyatakan ketentuan terkait } \\
\text { penghinaan Presiden bertentangan } \\
\text { 022/PUU- } \\
\text { IV/2006 }\end{array}$ & $\begin{array}{l}\text { dengan konstitusi dan tidak } \\
\text { mempunyai kekuatan hukum } \\
\text { mengikat. }\end{array}$ \\
\hline b. & $\begin{array}{l}\text { 31/PUU- } \\
\text { XIII/2015 }\end{array}$ & $\begin{array}{l}\text { Menyatakan ketentuan terkait } \\
\text { pencemaran nama baik } \\
\text { bertentangan dengan konstitusi } \\
\text { dan tidak mempunyai kekuatan } \\
\text { hukum mengikat. }\end{array}$ \\
\hline
\end{tabular}

\section{Tabel 2.}

Perubahan KUHP melalui Putusan Mahkamah Konstitusi.

49 Lihat www.dpr.go.id/uu/prolegnas, diakses pada tanggal 9 April 2018.

\section{Pidana Khusus}

\begin{tabular}{|c|c|c|}
\hline No & Bentuk & Substansi \\
\hline a. & $\begin{array}{l}\text { UU No. } 31 \\
\text { Tahun } 1999 \\
\text { jo. UU No. } 20 \\
\text { Tahun } 2001\end{array}$ & $\begin{array}{l}\text { Secara tidak langsung } \\
\text { mencabut Pasal } 415 \\
\text { dengan memuat pidana } \\
\text { kejahatan jabatan sebagai } \\
\text { salah satu bentuk korupsi. }\end{array}$ \\
\hline b. & $\begin{array}{l}\text { PERPU No. } 1 \\
\text { Tahun } 2002 \\
\text { jo. UU No. } 15 \\
\text { Tahun } 2003\end{array}$ & $\begin{array}{lr}\begin{array}{l}\text { Secara tidak langsung } \\
\text { mencabut } \\
\text { sebagaimana diatur dalam } \\
\text { Pasal 479a-Pasal }\end{array} \\
\text { 479f (yang } \\
\text { diubah melalui UU Nomor } 4 \\
\text { Tahun } 1976 \quad \text { terkait } \\
\text { kejahatan } \\
\text { penerbangan), sebagai salah } \\
\text { satu tindak pidana terorisme. }\end{array}$ \\
\hline c. & $\begin{array}{l}\text { UU No. } 21 \\
\text { Tahun } 2007\end{array}$ & $\begin{array}{lll}\text { Mencabut } & \text { Pasal } 293 \text { dan } \\
\text { Pasal } 324, & \text { terkait } \\
\text { Perdagangan Anak } & \end{array}$ \\
\hline d. & $\begin{array}{l}\text { UU No. } 11 \\
\text { Tahun } 2012\end{array}$ & $\begin{array}{l}\text { 1) Secara tidak langsung } \\
\text { memperbaiki sistem } \\
\text { peradilan anak; } \\
\text { 2) Mencabut UU Nomor } 3 \\
\text { Tahun } 1997 \quad \text { yang } \\
\text { mencabut Pasal 45- } \\
\text { Pasal 47). }\end{array}$ \\
\hline
\end{tabular}

Tabel 3.

Perubahan KUHP melalui UU Pidana Khusus.

Perubahan secara total terhadap KUHP sendiri sampai saat ini masih berproses, dan menjadi salah satu program prioritas di tahun 2018. ${ }^{49}$ Berdasarkan hal tersebut, tepatlah apa yang dinyatakan oleh Satjipto Rahardjo, terkait statisnya teks hukum sebagai berikut: ${ }^{50}$

\footnotetext{
50 Satjipto Rahardjo, op.cit., 50.
} 


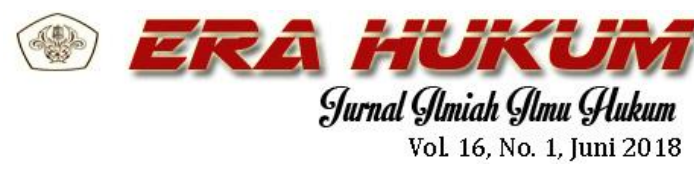

“Teks hukum tidak memiliki kepekaan untuk merasakan adanya sesuatu yang berubah. Hukum tidak mampu mengubah dirinya sendiri. Hukum tetap memuat teks yang sama, kecuali diubah oleh legislatif."

Lebih lanjut beliau menyatakan bahwa hal tersebut membawa pada doktrin kepastian hukum yang otomatis. Kekuatan hukum dipandang sebagai sesuatu yang taken for granted, yaitu dianggap ada dengan sendirinya tanpa perlu dikaji lebih jauh. Kekuatan hukum dianggap hadir bersamaan dengan kehadiran teks-teks hukum. ${ }^{51}$ Terlepas dari hal tersebut, terdapat kesadaran dari pembentuk undang-undang bahwa ketertinggalan materi muatan KUHP memang mendesak untuk dilakukan penyesuaian. Proses yang cukup lama untuk melakukan perubahan KUHP secara keseluruhan, menjadikan pembentuk undang-undang memilih untuk melakukan perubahan secara parsial melalui undangundang, karena materi muatan undangundang memang hanya bisa diubah dengan undang-undang.
Mohamad Rifki

Mengkaji Legalitas Peraturan Mahkamah Agung...

E. Batasan Fungsi Mengatur Mahkamah Agung dan Penemuan

\section{Hukum oleh Hakim}

Pada prinsipnya, semua bentuk pengaturan yang berasal dari kewenangan mengatur yang diberikan oleh undangundang memang sudah seharusnya tunduk kepada pengawasan oleh pembentuk undang-undang. Kewenangan di bidang peradilan atau rechtsprekende functie merupakan kewenangan mutlak yang bersifat inheren dan mutlak sebagai ranah kekuasaan judisial atau judikatif berdasarkan prinsip pemisahan kekuasaan (separation of power), sedangkan kewenangan pengadilan untuk pengaturan atau regelende functie bersumber dari delegasi kewenangan dari undang-undang atau pembentuk undang-undang. ${ }^{52}$

Oleh karena itu, hakim baru dapat dinyatakan melakukan penemuan hukum apabila dimuat dalam putusan bukan peraturan, karena fungsi pengaturan bukan dimiliki hakim, melainkan Mahkamah Agung sebagai lembaga yang didasarkan pada ketentuan dalam Pasal 79 UndangUndang Nomor 14 Tahun 1985 tentang Mahkamah Agung, sebagaimana telah dua kali diubah, terakhir dengan Undang-

52 Jimmly Asshiddiqie, Hukum Acara Pengujian Undang-Undang, (Jakarta: Yarsif Watampone, 2005), 37. 
Undang Nomor 3 Tahun 2009 (selanjutnya disebut UUMA), yang berbunyi sebagai berikut:

\begin{abstract}
"Mahkamah Agung dapat mengatur lebih lanjut hal-hal yang diperlukan bagi kelancaran penyelenggaraan peradilan apabila terdapat hal-hal yang belum cukup diatur dalam Undang-Undang ini."
\end{abstract}

Adapun penjelasan Pasal 79 UUMA tersebut, menyatakan dengan terang batasan fungsi pengaturan Mahkamah Agung sebagai berikut:

“Apabila dalam jalannya peradilan terdapat kekurangan atau kekosongan hukum dalam suatu hal, Mahkamah Agung berwenang membuat peraturan sebagai pelengkap untuk mengisi kekurangan atau kekosongan tadi. Dengan Undang-Undang ini Mahkamah Agung berwenang menentukan pengaturan tentang cara penyelesaian suatu soal yang belum atau tidak diatur dalam Undang-Undang ini. Dalam hal ini peraturan yang dikeluarkan oleh Mahkamah Agung dibedakan dengan peraturan yang disusun oleh pembentuk Undang-undang.

Penyelenggaraan peradilan yang dimaksudkan Undang-Undang ini hanya merupakan bagian dari hukum acara secara keseluruhan. Dengan demikian

${ }^{53}$ Henry Pandapotan Panggabean, Fungsi Mahkamah Agung Bersifat Pengaturan (Rule
Mahkamah Agung tidak akan mencampuri dan melampaui pengaturan tentang hak dan kewajiban warga negara pada umumnya dan tidak pula mengatur sifat, kekuatan, alat pembuktian serta penilaiannya ataupun pembagian beban pembuktian." (penebalan huruf oleh penulis)

\section{Menurut Henry Pandapotan} Panggabean dalam bukunya "Fungsi Mahkamah Agung Bersifat Pengaturan (Rule making Power) Tahun 1966-2003”, rumusan Pasal 79 UUMA tersebut membatasi kewenangan Mahkamah Agung dalam fungsi mengatur, dengan rincian: ${ }^{.53}$

1. Mahkamah Agung berwenang menentukan pengaturan tentang cara penyelesaian suatu soal yang belum atau tidak diatur dalam UUMA;

2. Pengaturan yang dikeluarkan Mahkamah Agung dibedakan dengan pengaturan yang disusun oleh pembentuk undangundang;

3. Penyelenggaraan peradilan yang dimaksud UUMA hanya merupakan bagian dari hukum acara secara keseluruhan.

Namun, menurut penulis perlu ditambahkan dua batasan lagi. Pertama,

making Power) Tahun 1966-2003, (Yogyakarta: Liberty, 2005), 1. 


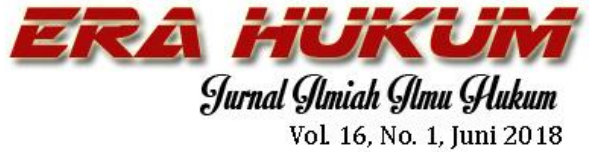

Perma tidak akan mencampuri dan melampaui pengaturan tentang hak dan kewajiban warga negara pada umumnya. Kedua, tidak mengatur sifat, kekuatan, alat pembuktian serta penilaiannya ataupun pembagian beban pembuktian. Dalam hal materi muatan Perma yang mengubah nilai rupiah sesungguhnya telah mengubah substansi atau materi muatan KUHP, sehingga telah melebihi batasan yang diberikan UUMA itu sendiri. Kelima batasan inilah yang harus disadari oleh Mahkamah Agung dalam menjalankan fungsi mengaturnya, agar tidak menyalahi kompetensinya.

Hal ini sesungguhnya telah disadari oleh Mahkamah Agung, bahwa untuk melakukan penyesuaian nilai rupiah dalam KUHP adalah kewenangan dari pembentuk undang-undang yakni DPR dengan Presiden. Oleh karena itu dalam salah satu konsideran Perma dinyatakan sebagai berikut:

Bahwa materi perubahan KUHP pada dasarnya merupakan materi undang-undang, namun mengingat perubahan KUHP diperkirakan akan memakan waktu yang cukup lama sementara perkara-perkara terus masuk ke pengadilan, Mahkamah Agung memandang perlu melakukan penyesuaian nilai rupiah yang ada dalam KUHP berdasarkan harga emas yang berlaku pada tahun 1960 .
Selain itu, Mahkamah Agung juga menyampaikan alasan pembentukan Perma dalam Penjelasan Umum dengan menyatakan bahwa:

“...Pemerintah dan DPR perlu melakukan perubahan atas KUHP, khususnya terhadap seluruh nilai rupiah yang ada dalam KUHP. Namun, mengingat sepertinya hal tersebut belum menjadi prioritas Pemerintah dan DPR, selain itu proses perubahan KUHP oleh Pemerintah dan DPR akan memakan waktu yang cukup lama, walaupun khusus untuk substansi ini sebenarnya mudah, untuk itu Mahkamah Agung memandang perlu menerbitkan Peraturan Mahkamah Agung ini untuk menyesuaikan nilai uang"

Berdasarkan hal tersebut, sekali lagi perlu ditegaskan bahwa ada kesadaran dari Mahkamah Agung bahwa materi dalam KUHP sesungguhnya materi undangundang, maka kewenangan perubahan ada pada DPR dan Presiden. Apabila melihat aspek historis, sesungguhnya perubahan terkait nilai rupiah dalam KUHP pernah dilakukan yakni melalui Undang-Undang Nomor 16 PRP Tahun 1960 dan UndangUndang Nomor 18 PRP Tahun 1960, sebagaimana telah disampaikan sebelumnya. Melihat hal tersebut, maka argumen yang dibangun Mahkamah Agung terkait proses perubahan KUHP yang akan 
memakan waktu cukup lama menjadi tidak cukup kuat, mengingat proses perubahan untuk penyesuaian nilai rupiah dapat dilakukan dengan penerbitan undangundang tersendiri yang muatannya mengubah substansi KUHP, tidak harus dengan KUHP sendiri secara utuh. Kalaupun membutuhkan waktu yang cepat dan memang dirasa ada unsur keterdesakkan, dimungkinkan mekanisme melalui Peraturan Pemerintah Pengganti Undang-Undang, tentunya dengan penyampaian dan koordinasi antara Mahkamah Agung dengan Pemerintah.

Substansi Perma bukanlah untuk mengisi kekosongan hukum, karena hukumnya sudah ada. Pembentukan Perma juga tidak menggunakan metode penemuan hukum sebagaimana telah diuraikan di atas. Menjadi terang bahwa Perma memang bukan produk penemuan hukum, melainkan peraturan. Karena berbentuk peraturan, maka secara hierarki perlu dikaji apakah ada pertentangan dengan peraturan perundangundangan di atasnya.

Dalam catatan penulis, produk Mahkamah Agung dari fungsi mengatur yang materi muatannya melebihi kewenangan Mahkamah Agung bukan kali ini saja terjadi. Salah satu contohnya adalah
Surat Edaran Mahkamah Agung Nomor 3 Tahun 1963, tanggal 5 September 1963, (selanjutnya disebut SEMA) yang isinya pendapat dari Mahkamah Agung bahwa Mahkamah Agung menganggap tidak berlaku lagi Pasal 108, Pasal 110, Pasal 284 ayat (3), Pasal 1682, Pasal 1579, Pasal 1238, Pasal 1460, Pasal 1603 Burgerlijk Wetboek (Kitab Undang-Undang Hukum Perdata). Terhadap SEMA tersebut, Sudikno Mertokusumo memberikan catatan sebagai berikut: ${ }^{54}$

1. problematik yang terdapat dalam pertimbangan SEMA tersebut kiranya kurang tepat, karena titik tolaknya adalah sifat keseluruhan dari Burgerlijk Wetboek itu sendiri yang dinyatakan kolonial. Memang benar Burgerlijk Wetboek itu dilahirkan di zaman kolonial/penjajahan, meskipun demikian tidak adakah ketentuan di dalam Burgerlijk Wetboek yang bersifat universal dan perlu dipertahankan? Benarkah seluruh Burgerlijk Wetboek itu sudah usang?

2. gagasan tersebut di atas dituangkan dalam SEMA sebagai konsekuensi karena telah diajukan oleh Menteri Kehakiman Sahardjo, S.H., pada sidang Badan Perancang dari Lembaga Pembina Hukum Nasional (Mei 1963) dan setelah ditawarkan oleh Ketua Mahkamah Agung

\footnotetext{
${ }^{54}$ Sudikno Mertokusumo, Bunga Rampai Ilmu
} Hukum, op.cit., 10-11. 


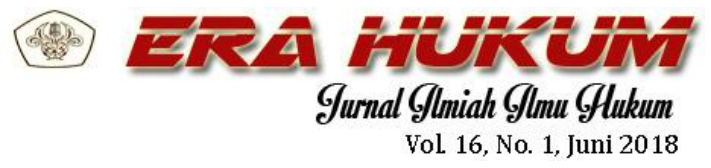

kepada khalayak ramai dalam seksi Hukum Kongres Majelis Ilmu Pengetahuan Indonesia (Oktober 1963) mendapat persetujuan bulat. Di samping itu banyak sarjana-sarjana hukum yang menyetujuinya. Bukankah pertimbangan ini lebih bersifat politis naif daripada yuridis?

3. kalau Burgerlijk Wetboek dikutuk sebagai bersifat colonial, mengapa masih dipertahankan sebagai "dokumen yang hanya menggambarkan suatu kelompokan hukum tak tertulis"?

4. sikap menganggap Burgerlijk Wetboek tidak berlaku lagi berarti meniadakan Burgerlijk Wetboek sebagai undangundang. Wewenangkah Mahkamah Agung meniadakan atau mencabut undang-undang dengan suatu surat edaran? Mahkamah Agung adalah lembaga yudikatif dan bukan lembaga legislative. Dengan demikian Mahkamah Agung telah melanggar wewenangnya, Mahkamah Agung telah melanggar ajaran tentang kompetensi.

5. kalau ada seorang hakim di dalam putusannya melanggar SEMA tersebut apakah putusan itu dapat dibatalkan (cassabel) oleh Mahkamah Agung?

6. apakah SEMA itu tidak membatasi kebebasan hakim?

Masih menurut Sudikno, meskipun maksud dari SEMA itu memang baik, yaitu

\footnotetext{
55 ibid., 11.

56 ibid., 193.
}

agar hukum menyesuaikan dengan perkembangan masyarakat, dalam hal ini Mahkamah Agung terlalu jauh melangkah. Mengapa tidak menyerahkannya saja kepada hakim untuk menyesuaikan/menafsirkan Burgerlijk Wetboek dengan keadaan di dalam putusan, karena hakim memiliki kebebasan untuk itu. ${ }^{55}$ Catatan serupa juga patut diberikan atas Perma.

Kedudukan Mahkamah Agung sebagai lembaga yudikatif, maka apa yang dapat dibuat atau diciptakan oleh Mahkamah Agung bukanlah peraturan yang bersifat umum mengikat setiap orang. Bukanlah hukum material yang dibuatnya. Bukanlah law making yang dilakukannya karena Mahkamah Agung bukan pembentuk undang-undang, tetapi yang dilakukannya ialah rule making, karena hanya membuat "aturan permainan" yang hanya berlaku bagi atau mengikat para "pemain" dalam “permainan peradilan" yaitu para hakim. ${ }^{56}$ Hal yang perlu diperhatikan oleh Mahkamah Agung ialah agar jangan sampai Mahkamah Agung melanggar competentieleer sehingga melakukan law making. ${ }^{57}$ Oleh karena itu batasan fungsi mengatur Mahkamah Agung sesungguhnya telah diatur dalam Pasal 79 UUMA, yakni “...hal-hal yang diperlukan 57 ibid. 


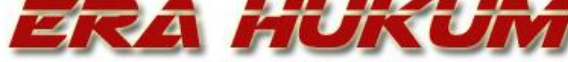 \\ Gurnal Glmiah Glmu Glukum \\ Vol 16, No. 1, Juni 2018}

bagi kelancaran penyelenggaraan peradilan..."

Selaras prinsip separation of power, kewenangan membuat peraturan yang bersifat mengikat dan membatasi kebebasan setiap warga negara bukanlah merupakan kewenangan Mahkamah Agung sebagai lembaga yudikatif, tetapi menjadi ranah dari lembaga legislatif. Selain itu, sesuai prinsip judge made law di dalam sistem hukum Eropa Kontinental dalam bentuk rechtshepping, seharusnya Mahkamah Agung menciptakan hukum melalui putusan-putusan hakim. Utamanya, jika belum tersedianya aturan perundangundangan yang dapat memenuhi kebutuhan hukum masyarakat. ${ }^{58}$

Kesadaran Mahkamah Agung sebagaimana tertuang dalam Penjelasan Umum Perma yang telah diuraikan sebelumnya, sebaiknya menjadi pertimbangan para hakim dalam membuat penemuan hukum. Diantara metode penemuan hukum yang ada, hakim dapat saja menggunakan metode interpretasi teleologis atau sosiologis. Interpretasi ini lebih menafsirkan undang-undang sesuai

58 BPHN, Laporan Akhir Pengkajian Hukum tentang Eksistensi Peraturan Perundang-Undangan di luar Hierarki Berdasarkan Undang-Undang Nomor 10 Tahun 2004 tentang Pembentukan Peraturan Perundang-Undangan, (Jakarta: BPHN, Kementerian Hukum dan Hak Asasi Manusia, 2010), 52. dengan tujuan pembentuk undang-undang daripada bunyi kata-kata dari undangundang tersebut. ${ }^{59}$ Interpretasi teleologis juga harus memperhitungkan konteks kenyataan kemasyarakatan yang aktual. ${ }^{60}$ Selain itu, adanya rancangan undangundang KUHP yang akan menggantikan KUHP yang masih berlaku saat ini, maka hakim dapat pula menggunakan metode interpretasi antisipatif atau interpretasi futuristis, yaitu penafsiran dengan menggunakan peraturan yang belum mempunyai kekuatan berlaku karena masih dalam rancangan undang-undang. ${ }^{61}$

\section{Penutup}

\section{A. Kesimpulan}

Penemuan hukum oleh hakim berbeda dengan peraturan yang ditetapkan Mahkamah Agung selaku lembaga negara. Penemuan hukum merupakan kewenangan mandiri seorang hakim dalam membuat putusan, sedangkan peraturan yang ditetapkan merupakan fungsi mengatur yang diberikan oleh undang-undang dengan batasan tertentu. Dalam hal terdapat undangundang tidak jelas atau dirasa tertinggal

59 Sudikno Mertokusumo, Penemuan Hukum, op.cit., 61.

60 J.A. Pontier, Penemuan Hukum, (Bandung: Jendela Mas Pustaka, 2008), sebagaimana dikutip dalam Eddy O.S. Hiariej, op.cit., 67.

${ }^{61}$ Sudikno Mertokusumo, Penemuan Hukum, op.cit., 62. 
dengan kondisi masyarakat, maka peran hakim untuk dapat menemukan hukum yang perlu diutamakan.

Ketika pemenuhan hukum itu dilakukan dengan Perma, legalitasnya dipertanyakan. Meskipun secara positif belum dapat dikatakan Perma bertentangan dengan undang-undang, karena belum diuji oleh Mahkamah Agung, ${ }^{62}$ secara teori sudah jelas bahwa materi muatan KUHP tidak dapat dinegasikan oleh Perma, dengan alasan apapun. Terpenuhinya Unsur formal hanya sebatas bahwa Mahkamah Agung memiliki kewenangan membentuk Perma karena fungsi mengatur yang dimiliki, namun unsur material tidak terpenuhi, karena materi muatan yang tidak tepat.

\section{B. Saran}

Mahkamah Agung harus dapat membedakan fungsi mengatur selaku lembaga negara dengan kewenangan melakukan penemuan hukum yang dimiliki oleh hakim. Fungsi mengatur yang dimiliki oleh Mahkamah Agung cukup memberikan "aturan main" kepada para hakim tanpa

${ }^{62}$ Menjadi permasalahan kemudian, ketika hak uji materi atas Perma dilakukan oleh Mahkamah Agung yang menerbitkan Perma itu sendiri. Jelas terdapat konflik kepentingan disini. Jimly Asshiddiqie, dalam bukunya Hukum Acara Pengujian Undang-Undang, menyatakan bahwa dalam rangka check and balances dalam sistem membelenggu hak hakim untuk melakukan penemuan hukum.

Mahkamah Agung jangan sampai melanggar kompetensinya sendiri sebagai lembaga yudikatif, meskipun memiliki fungsi mengatur yang didapatkan dari undang-undang, karena UUMA memberikan batasan sejauh mana materi muatan yang dapat diatur oleh Mahkamah Agung. Pengaturan yang terlalu jauh dari kewenangan Mahkamah Agung menjadikan legalitas Perma dipertanyakan, terutama bila materi muatan tersebut merupakan materi muatan undang-undang atau bahkan bertentangan dengan undang-undang.

\section{DAFTAR PUSTAKA}

\section{A. Buku}

Anggono, Bayu Dwi. Perkembangan Pembentukan Undang-Undang di Indonesia. Jakarta, Konstitusi Press, 2014.

Asshiddiqie, Jimly. Perihal UndangUndang. Jakarta: Rajawali Pers, 2014

ketatanegaraan di masa datang, sangat penting adanya pengawasan dari lembaga pembentuk undang-undang dalam hal ini DPR agar Mahkamah Agung maupun Mahkamah Konstitusi tidak sewenang-wenang dalam membuat dan menetapkan Peraturan Mahkamah Agung ataupun Peraturan Mahkamah Konstitusi. 


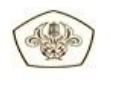

. Pengantar Ilmu Hukum

Tata Negara. Jakarta: Rajawali

Pers, 2013.

\section{Penguatan Sistem}

Pemerintahan dan Peradilan.

Jakarta: Sinar Grafika, 2015.

\begin{tabular}{lc} 
Hukum Acara \\
\hline Pengujian & Undang-Undang.
\end{tabular}

Jakarta: Yarsif Watampone, 2005.

BPHN. Laporan Akhir Pengkajian Hukum

tentang Eksistensi Peraturan

Perundang-Undangan di luar

Hierarki Berdasarkan Undang-

Undang Nomor 10 Tahun 2004

tentang Pembentukan Peraturan

Perundang-Undangan. Jakarta:

BPHN, Kementerian Hukum dan

Hak Asasi Manusia, 2010.

Fatmawati. Hak Menguji (Toetsingsrecht)

yang dimiliki Hakim dalam Sistem

Hukum Indonesia. Jakarta:

RajaGrafindo, 2005.

Hart, H.L.A. Konsep Hukum.

Bandung: Nusa Media, 2016.

Hiariej, Eddy O.S. Asas Legalitas dan Penemuan Hukum dalam Hukum Pidana. Jakarta: Erlangga, 2016.

Indrati S., Maria Farida. Ilmu Perundangundangan, jilid I. Yogyakarta: Kanisius, 2017.

Ilmu

Perundang-undangan,
Mengkaji Legalitas Peraturan Mahkamah Agung...

jilid II. Yogyakarta: Kanisius, 2017.

Mertokusumo, Sudikno. Bunga Rampai Ilmu Hukum. Yogyakarta: Liberty, 2015.

Penemuan

Hukum. Yogyakarta: Liberty, 2009. . Mengenal Hukum.

Yogyakarta: Cahaya Atma

Pustaka, 2016.

Manan, Bagir. Konvensi Ketatanegaraan. Yogyakarta: UII Press, 2006.

Panggabean, Henry Pandapotan. Fungsi Mahkamah Agung Bersifat Pengaturan (Rule making Power) Tahun 1966-2003. Yogyakarta: Liberty, 2005.

Rahardjo, Satjipto. Lapisan-lapisan dalam Studi Hukum. Malang: Bayumedia, 2009.

Widodo, J. Pajar. Menjadi Hakim Progresif. Bandar Lampung: Indepth Publishing, 2013.

\section{B. Peraturan Perundang-undangan}

Undang Undang Dasar Negara Republik Indonesia Tahun 1945.

Indonesia, Undang-Undang Nomor 14 Tahun 1985 tentang Mahkamah Agung (Lembaran Negara Republik Indonesia Tahun 1985 


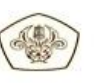

Nomor 73, Tambahan Lembaran

Negara Republik Indonesia Nomor

3316), sebagaimana telah dua kali

diubah, terakhir dengan Undang-

Undang Nomor 3 Tahun 2009

(Lembaran Negara Republik

Indonesia Tahun 2009 Nomor 3,

Tambahan Lembaran Negara

Republik Indonesia Nomor 4958). , Undang-Undang Nomor 48

Tahun 2009 tentang Kekuasaan

Kehakiman (Lembaran Negara

Republik Indonesia Tahun 2009

Nomor 157, Tambahan Lembaran

Negara Republik Indonesia Nomor 5076).

, Undang-Undang Nomor 12

Tahun 2011 tentang Pembentukan

Peraturan Perundang-undangan

(Lembaran Negara Republik

Indonesia Tahun 2011 Nomor 82,

Tambahan Lembaran Negara

Republik Indonesia Nomor 5234).

\section{Jurnal}

Hidayat, Arief. "Penemuan Hukum melalui

Penafsiran Hakim dalam Putusan

Pengadilan." Pandecta. Volume 8,

Nomor 2 (Juli 2013): 153-169.
Mohamad Rifki

Mengkaji Legalitas Peraturan Mahkamah Agung...

\section{Website}

www.dpr.go.id/uu/prolegnas,

diakses tanggal 9 April 2018. 